element might be recognized by a dimer of two identical monomers of the oestrogen receptor. The observation that the exchange of only two bases at homologous positions within the 15-bp palindrome, altering the hetanucleotide TGACCT to TGTCCT, leads to a loss of oestrogen response and to glucocorticoid induction, corresponds with a similarity in structure $(62 \%$ homology of amino-acid sequence) of the DNA-binding regions of the respective hormone receptors ${ }^{7}$. These findings are consistent with the probable coevolution of the DNA-binding region of steroid receptors and of the DNA sequences which they recognize.

We wish to thank Dr F. Rösl for synthesis of the oligonucleotides, Drs W. Schmid, R. Miksicek and G. Kelsey for discussion and Ms P. Di Noi for typing the manuscript. This work was supported by the Deutsche Forschungsgemeinschaft (G.K.). Note added in proof: Similar results have been obtained by W. Wahli's group (E. Martinez et al. EMBO J., in the press) and G. Ryffel's group (personal communication).

Received 18 May; accepted 10 September 1987.

1. Yamamoto, K. R. A. Rev. Genet. 19, 209-252 (1985)

Ringold, G. A. Rev. Pharmac. Tox. 25, 529-566 (1985).

Scheidereit, C., Westphal, H. M., Carlson, C., Bosshard, H. \& Beato, M. DNA 5, 383-391 (1986)

4. Jantzen, H.-M. et al. Cell 49, 29-38 (1987).

5. Strähle, U., Klock, G. \& Schütz, G. Proc. natn. Acad. Sci. U.S.A. (in the press).

6. Walker, P., Germond, J.-E., Brown-Luedi, M., Givel, F. \& Wahli, W. Nucleic Acids Res. $12,8611-8626$ (1984).

Green, S. \& Chambon, P. Nature 324, 615-617 (1986).

Klein-Hitpass, L., Schorpp, M., Wagner, U. \& Ryffel, G. U. Cell 46, 1053-1061 (1986).

Seiler-Tuyns, A. et al. Nucleic Acids Res. 14, 8755-8770 (1986)

10. Horwitz, K. B., Zava, D. T., Thilagar, A. K., Jensen, E. M. \& McGuire, W. L. Cancer Res. 38, 2434-2437 (1978).

11. Gorman, C. M., Moffat, L. F. \& Howard, B. H. Molec. cell. Biol. 2, 1044-1051 (1982)

12. Zinn, K., DiMaio, D. \& Maniatis, T. Cell 34, 865-879 (1983).

13. Melton, D. A et al Nucleic Acids Res. 12, $7035-7056$ (1984).

14. Miksicek, R. et al. Cell 46, 283-290 (1986).

15. King, R. J. B. \& Mainwaring, W. J. P. in Steroid-Cell Interactions (Butterworth, London, 1974)

16. Rochefort, H., Garcia, M., Vignon, F. \& Westley, B. in Steroid induced uterine proteins (ed. Beato, M.). 171-182 (Elsevier, Amsterdam, 1980).

17. Dabre, P., Page, M. \& King, R. J. B. Molec. cell. Biol, 6, 2847-2854 (1986)

18. Cato, A. C. B., Henderson, D. \& Ponta, H. EMBO J. 6, 363-368 (1987).

19 Luckow, B. \& Schütz, G. Nucleic Acids Res. 15, 5490 (1987).

\section{Different rhinovirus serotypes neutralized by antipeptide antibodies}

\section{Joseph McCray \& Gudrun Werner}

Sandoz Forschungsinstitut, Brunner Strasse 59, A-1235 Vienna, Austria

Recently, Rossman et al. ${ }^{1}$ have described the three-dimensional structure of a human rhinovirus. A possible host cell surface receptor binding site was identified with a cleft on each icosahedral face. Two highly conserved amino-acid sequences found in rhino-, polio-, and foot-and-mouth disease (FMD) viruses are located near the base of this site and could be important in maintaining its topology. We have prepared site-specific antibodies ${ }^{2,3}$ to two synthetic peptides which include these sequences. The antibodies bind to the predicted capsid proteins of rhinovirus and neutralize $\sim 60 \%$ of 48 rhinovirus serotypes tested. These results could provide a route to a rhinovirus vaccine effective against most of the numerous serotypes of this virus.

The two conserved viral amino-acid sequences postulated by Rossmann et al. ${ }^{1}$ to be structurally important in a proposed host cell receptor binding site are amino acids 151-160 (MYVPPGAPNP, using single-letter code) of capsid protein VP1 and 130-139 (AYTPPGARGP) of VP3 of the human rhinovirus serotype 14 (HRV14) (ref. 1). We have used two synthetic peptides corresponding to amino acids 147-162 (VVQAMYVPPGAPNPKEC, designated PVP1A) of VP1 and 126-141 of VP3 (KLILAYTPPGARGPQDC, designated PVP3A) of HRV14, attached to keyhole limpet haemocyanin

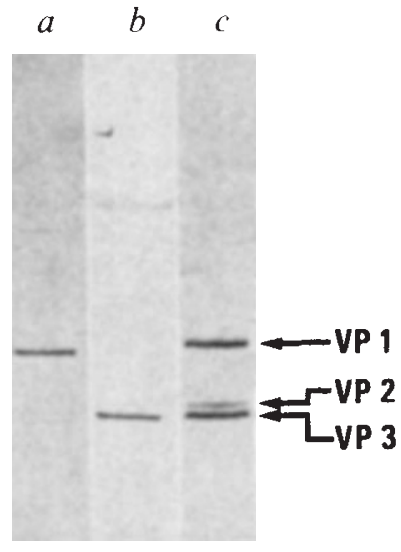

Fig. 1 Immunoblotting of rhinovirus capsid proteins with antipeptide antibodies. $a$, Immunostaining with anti-PVP1A antibodies at a concentration of $40 \mu \mathrm{g} \mathrm{ml}^{-1}$. b, Anti-PV3A antibodies at $80 \mu \mathrm{g} \mathrm{ml}^{-1}$. $c$, Control with an anti-HRV14 hyperimmune serum at $1: 60$ dilution.

Methods. HRV14 virus particles were purified as previously described $^{15}$. Viral capsid proteins were separated by $5-20 \%$ SDSpolyacrylamide-gradient gel electrophoresis and blotted on to nitrocellulose sheets ${ }^{16}$. Antibodies against commercially synthesized peptides PVP1A and PVP3A (Bachem) were induced by immunization of rabbits with keyhole limpet haemocyanin conjugates ${ }^{17}$. The antipeptide antibodies were purified from sera by affinity chromatography with columns of peptide attached to agarose. Antibody activity against the peptides was followed with ELISA (ref. 17). Visualization of immune complexes was done with a commercial horseradish-peroxidase conjugated goat antirabbit $\operatorname{lgG}$ at $1: 3,000$ dilution.

(KLH) by an additional cysteine residue, to raise polyclonal antibodies in rabbits. Purified antibodies were tested for binding to the capsid proteins of HRV14 and for neutralization of different rhinovirus serotypes and of other picornaviruses.

Immunoblotting (Fig. 1) demonstrated that antipeptide antibodies bound to viral proteins as expected: antibodies to PVP1A bound strongly to VP1 and very weakly to VP3, and the opposite was found for anti-PVP3A antibodies. In enzyme-linked immunosorbent assay (ELISA) tests with the peptides (data not shown) a similar cross-reactivity was observed. This is explained by both peptides having the common sequence PPGA. A competition experiment demonstrated that the free peptides partially inhibited binding of their respective antibodies in immunoblotting (data not shown).

In ELISA tests using purified HRV14, both antipeptide antibodies recognized whole virus (Fig. 2). Competition is shown between increasing concentrations of the respective free peptide and HRV14 for antibody binding, but is not observed for an unrelated peptide. This implies that the observed binding is site-specific (Fig. 2),

Both purified rabbit polyclonal antipeptide antibodies neutralized HRV14 equally well (Table 1). Protection against infectivity was complete at low antibody dilutions, although titres were low compared to a rabbit antiserum against purified intact virus (Table 2). A commercial purified rabbit IgG preparation and purified rabbit antibodies against an unrelated peptide showed no neutralization. The relatively low neutralization titres agree with the frequent observation that antibodies against peptide partial sequences recognize the intact parent protein with a lower affinity compared to antibodies against the intact protein ${ }^{4}$. This has been noted for influenza ${ }^{3,5}$, hepatitis A (ref. 6), herpes ${ }^{7}$ and polio viruses ${ }^{8,9}$.

In an attempt to more closely define a neutralizing epitope, the affinity-purified anti-PVP1A antibodies were fractionated further on an affinity column containing bound PVP3A. About $10 \%$ of the anti-PVP1A antibodies bound to the column. These cross-reacting antibodies were found to neutralize HRV14 very 

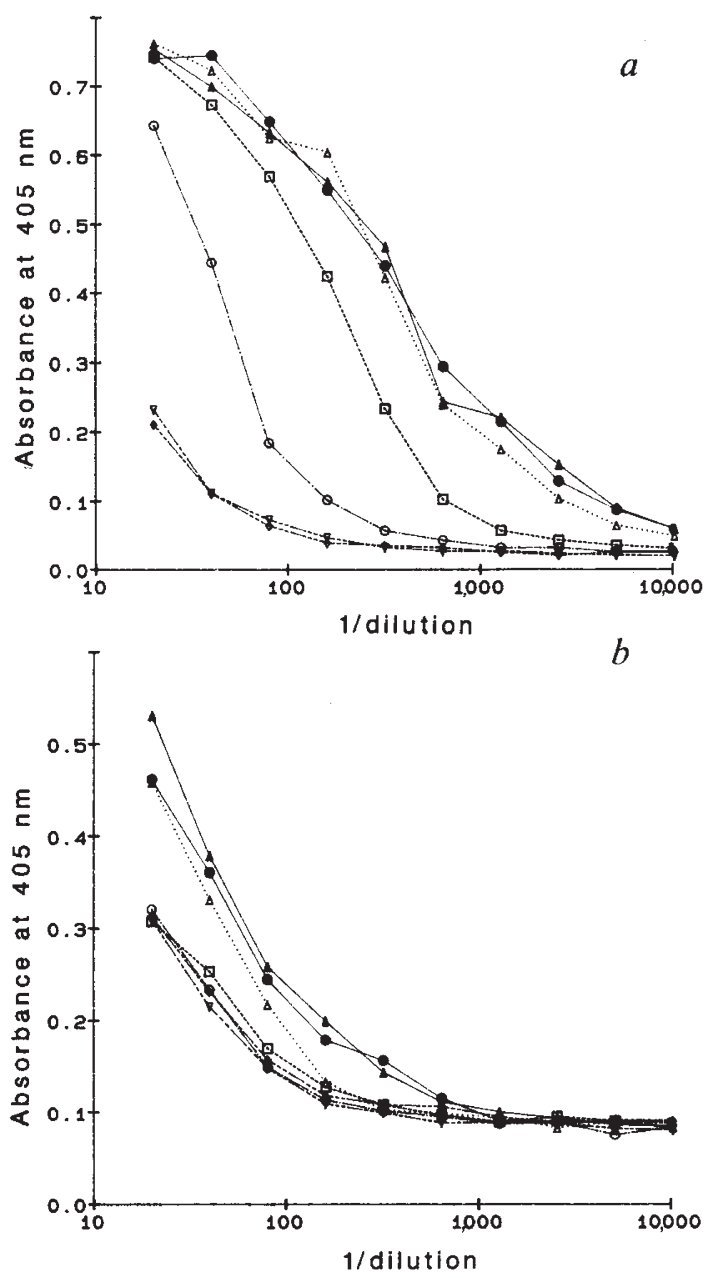

Fig. 2 ELISA to measure the binding of antipeptide antibodies to rhinovirus 14 particles in the presence of increasing concentrations of peptide. $a$, Anti-PVP1A: $\triangle---\Delta$, PBS $+1 \%$ BSA; $\triangle---\Delta, \quad+1 \mathrm{ng} \quad \mathrm{ml}^{-1} \quad$ PVP1A; $\square---\square, \quad+10 \mathrm{ng} \mathrm{ml}^{-1}$; $\bigcirc---\bigcirc,+100 \mathrm{ng} \mathrm{ml}^{-1} ; \nabla---\nabla,+1 \mu \mathrm{g} \mathrm{ml}^{-1} ; \diamond--\diamond,+10 \mu \mathrm{g}$ $\mathrm{ml}^{-1} ; 0_{-}-0,-10 \mu \mathrm{g} \mathrm{ml}^{-1}$ control peptide. $b$, Anti-PVP3A: $\Delta--\Delta, \quad$ PBS $+1 \% \quad$ BSA $+0.35 \mathrm{M} \quad \mathrm{NaCl}+0.1 \% \quad$ Tween-20; $\triangle---\triangle,+10 \mathrm{ng} \mathrm{ml}^{-1}$ PVP3A; $\square---\square,+100 \mathrm{ng} \mathrm{ml}^{-1} ;$ O $---\bigcirc$, $+1 \mu \mathrm{g} \mathrm{ml} l^{-1} ; \nabla---\nabla,+10 \mu \mathrm{g} \mathrm{ml}^{-1} ; \diamond--\diamond \diamond,+50 \mu \mathrm{g} \mathrm{ml}^{-1}$; - - - $+50 \mu \mathrm{g} \mathrm{ml}^{-1}$ control peptide. The control peptide was a 13-amino-acid sequence from human granulocyte and macrophage colony stimulating factor with an additional Cterminal cysteine residue. Although in these experiments the virus was dried on to the plates and fixed with methanol, results are similar for virus adsorbed to plates without drying or fixation (data not shown). It is not possible to know the form of the antigen present on the surface of the ELISA plate in either test.

Methods. $50 \mu \mathrm{l}$ purified HRV14 $(1: 40$ dilution in PBS at $\sim 100 \mu \mathrm{g} \mathrm{ml}^{-1}$ protein, equivalent to $\sim 8 \times 10^{12}$ virus particles $\mathrm{ml}^{-1}$ ) was added to each well of a microtitration plate. Control wells received only PBS. The plates were dried overnight at $37^{\circ} \mathrm{C}$ and fixed with $50 \mu 1$ methanol per well for $5 \mathrm{~min}$. The plates were dried and nonspecific binding sites blocked with $3 \%(\mathrm{w} / \mathrm{v})$ bovine serum albumin (BSA) in PBS. Twofold dilutions of purified anti-PVP1A $\left(0.58 \mathrm{mg} \mathrm{ml}^{-1}\right)$ and anti-PVP3A $\left(1 \mathrm{mg} \mathrm{ml}^{-1}\right)$ in PBS $+1 \%$ BSA (the anti-PVP3A buffer also contained $0.35 \mathrm{M} \mathrm{NaCl}$ and $0.1 \%$ Tween20) were incubated with different concentrations of either PVP1A or PVP3A in PBS $+1 \%$ BSA or with a control peptide unrelated to rhinovirus. After incubation for $10 \mathrm{~min}$ at room temperature these samples were added to the plates containing fixed rhinovirus. The ELISA was then continued according to normal procedure. Detection of bound antibody was done with anti-rabbit immunoglobulin $\mathrm{F}\left(\mathrm{ab}^{\prime}\right)_{2}$-fragments from donkey linked to $\beta$-galactosidase (Amersham) using orthonitrophenylgalactoside as substrate. Absorbance was measured at $405 \mathrm{~nm}$ with an automatic microtitration plate photometer. The values shown are the average of duplicate determinations.
Table 1 Microneutralization test of HRV14 with antipeptide antibodies

\begin{tabular}{lcc}
\hline $\begin{array}{c}\text { Antibody } \\
\text { preparation }\end{array}$ & $\begin{array}{c}\text { Concentration } \\
\text { of antibodies* } \\
\left(\mu \mathrm{gl}^{-1}\right)\end{array}$ & $\begin{array}{c}\text { Activity in MNT } \\
(\text { neutralizing titer })\end{array}$ \\
$\begin{array}{l}a, \text { Anti-PVP1A } \\
b, \text { Anti-PVP3A }\end{array}$ & 18 & $+(1: 64)$ \\
$c$, Anti-PVP1A-PVP3A & 12 & $+(1: 64)$ \\
$d$, Anti-PVP1A-PVP3A & 120 & - \\
$e$, Rabbit IgG & 7 & $+(1: 32)$ \\
\hline
\end{tabular}

All antibody preparations except rabbit IgG were purified by affinity chromatography, using peptide Affigel columns. Peptides were coupled to Affigel by $\mathrm{N}$-maleoyl- $\boldsymbol{\beta}$-alanyl- $\mathrm{N}$-hydroxysuccinimide ester as described $^{17} . c$ and $d$ are fractions from a second purification step of anti-PVP1A antibodies on a PVP3A-affinity column: $c$, contains antibodies in the flow-through and $d$, contains antibodies eluted from the column. The microneutralization test (MNT) was performed as follows: in a microtitration plate $100 \mu \mathrm{l}$ test antibody was serially diluted $(1: 2)$ in MEM-Eagle, supplemented with $2 \%$ FCS, $1 \%$ penicillin and streptomycin, and $40 \mathrm{mM} \mathrm{MgCl}$ and preincubated for $1 \mathrm{~h}$ at $34^{\circ} \mathrm{C}$, after addition of $50 \mu 1$ rhinovirus, diluted in the same medium to $1 \times 10^{4}$ PFU ml ${ }^{-1} .50 \mu \mathrm{l}$ freshly trypsinized HeLa-Ohio cells $\left(3 \times 10^{5}\right.$ cells $\left.\mathrm{ml}^{-1}\right)$ were then added to each well and incubated at $34^{\circ} \mathrm{C}$ in a humidified $5 \% \mathrm{CO}_{2}$ atmosphere until the cytopathic effect of the virus in control wells was complete (usually 2-3 days). The remaining cells were stained with crystal violet and the absorbance measured at $577 \mathrm{~nm}$ in an automatic ELISA-reader.

* Values indicate minimum concentrations of antibodies needed to neutralize HRV14 in MNT or the maximum concentrations tested if no neutralization was detected $(c$ and $e$ ).

efficiently (Table 1), but antibodies in the flow-through showed almost no neutralization activity. Because PVP1A and PVP3A have only the sequence PPGA in common, these results indicate that antibodies primarily directed against this sequence can neutralize HRV14.

The high degree of conservation of the two peptide sequences in rhino, polio and FMD viruses ${ }^{1}$ suggests that the antipeptide antibodies could neutralize other picornaviruses as well as other rhinovirus serotypes. The neutralization by our antipeptide antibodies of other rhinovirus serotypes was variable. Both antibodies gave similar results, and in some cases neutralization was tested with only one antibody preparation. Of the serotypes tested so far, $25 \%$ were neutralized as effectively as, or better than, HRV14; another $33 \%$ were neutralized rather less effectively than HRV14. Altogether $\sim 60 \%$ of the serotypes tested were neutralized to some extent. We have also found a comparatively low degree of neutralization of a few other serotypes with an antiserum against intact purified HRV14, but, compared to the cross-reactivity seen with the antipeptide antibodies, relatively few other serotypes were neutralized by the anti-HRV14 antiserum, and the corresponding titres were in all cases $<1 \%$ of the titre against HRV14. Surprisingly, the other picornaviruses, polio (1 and 2), coxsackie B3 and echovirus 9, were not neutralized by the antipeptide antibodies.

Recently it has been shown that the rhinoviruses can be divided into two groups recognizing different receptors ${ }^{10}$; HRV14 belongs to the larger one comprising about $80 \%$ of all serotype ${ }^{10}$. It is interesting that no member tested from the minor group (serotypes 1a, 2, 47, and 62) was neutralized by the antipeptide antibodies (Table 1). The sequence of HRV2 has a number of amino-acid changes in the peptide sequences tested, which might preclude recognition by the antipeptide antibodies. Unfortunately no sequences of serotypes other than HRV14 or HRV2 are available, so we do not know if neutralization by our antipeptide antibodies correlates with conservation of the target sequences.

Our results show that antipeptide antibodies against sequences conserved among some picornaviruses can bind to intact virions of a large number of rhinovirus serotypes, thereby 
Table 2 Neutralization of human rhinoviruses by anti-peptide antibodies

\begin{tabular}{ll}
\multicolumn{1}{c}{$\begin{array}{c}\text { Neutralizing } \\
\text { activity }\end{array}$} & \multicolumn{1}{c}{ Serotype tested } \\
$\begin{array}{l}\text { Weak } \\
(<1: 8)\end{array}$ & $9 \dagger, 10,16,40 \dagger, 45 \dagger, 68^{*}, 71 \dagger$ \\
$\begin{array}{l}\text { Normal } \\
(1: 8-1: 32)\end{array}$ & $17 \dagger, 24,26 \dagger, 28,32 \dagger, 36,51,58 \dagger, 72^{*}$ \\
$\begin{array}{l}\text { Strong } \\
(>1: 32)\end{array}$ & $3^{*}, 5 \dagger, 6,14,23,27,35 \dagger, 37 \dagger, 48 \dagger, 50,55^{*}, 64$ \\
None & $\underline{1 \mathrm{a}}, \underline{\mathbf{2}}^{\mathbf{4}}, 4,7,8,13,15,18,19,20,21,22,25,33,38$, \\
& $\left(\right.$ polio $1, \underline{62^{*}}, 75,85$ \\
&
\end{tabular}

Grouping of viruses was according to absorbance values $(577 \mathrm{~nm})$ of stained cells surviving in the virus neutralization test (as described in legend to Table 1). Reference values were from cells infected with untreated virus (blank) and from uninfected control cells (maximum values). Titres indicate dilutions of antibodies giving lysis of infected cells comparable to controls. Viruses underlined belong to a minor group of rhinoviruses using another receptor for cell penetration ${ }^{10}$.

* These serotypes were weakly positive with a rabbit hyperimmune serum against HRV14 whole virus particles. Titres ranged between 1:20 (HRV3) and 1:640 (HRV55) compared to 1:80,000 for HRV14.

$\dagger$ These viruses were negative with the anti-HRV14-hyperimmune serum.

neutralizing their infectivity. Therefore these sequences are probably at least partially conserved among different rhinovirus serotypes.

Although the mechanism of neutralization ${ }^{12}$ cannot be deduced from these results, it is possible that our antipeptide antibodies block the putative cell surface receptor binding site proposed by Rossmann et al. ${ }^{1}$. Both peptides include residues exposed in this site as well as exposed amino acids not actually in the site (refs 1, 13 and M. G. Rossman, personal communication). Antibodies we presume are directed primarily against the highly conserved sequence PPGA neutralize rhinovirus (Table 1); this sequence is partially exposed in the cleft proposed as the receptor binding site, but the crystallographic data predicts that it should not be accessible to antibody molecules. It is necessary to now identify the exact contact residues in the new neutralizing epitope detected by our antipeptide antibodies.

The data reported here support the feasibility of a synthetic peptide vaccine against rhinoviruses, perhaps incorporating several short peptides necessary to ensure immunization against all the serotypes ${ }^{14}$, but the absence of an animal model makes in vivo testing for protection against rhinovirus infection difficult.

We are grateful to M. Pibermann, V. Weber and G. Winkler for technical assistance and to B. Rosenwirth who supplied various rhinovirus serotypes. We thank Professor M. Rossmann for discussion and communication of unpublished results.

\section{Received 15 May; accepted 1 September 1987}

1. Rossmann, M. G. et al. Nature 317, 145-153 (1985)

2. Lerner, R. A. Adv. Immun. 36, 1-44 (1984).

3. Shinnick, T. M., Sutcliffe, J. G., Green, N. \& Lerner, R. A. A. Rev. Microbiol. 37, 425-446 (1983).

4. Hirayama, A., Takagaki, Y. \& Karush, F. J. Immun. 134, 3241-3247 (1985)

5. Mueller, G. M., Shapira, M. \& Arnon, R. Proc. natn. Acad. Sci. U.S.A. 79, 569-573 (1982)

6. Emini, E. A Hughes, J V Perlow, D. S. \& Boger, J, J. Virol. 55, 836-839 (1985).

6. Emini, E. A., Hughes, J. V., Perlow, D. S. \& Boger,

7. Cohen, G. H. et al. J. Virol. 49, 102-108 (1984).
8. Emini, E. A., Jameson, B. A. \& Wimmer, E. J. Virol. 52, 719-721 (1984).

9. Chow, M., Yabrov, R., Bittle, J., Hogle, J. \& Baltimore, D. Proc. natn. Acad. Sci. U.S.A. 82, 910-914 (1985).

10. Colonno, R. J., Callahan, P. L. \& Long, W. J. J. Virol. 57, 7-12 (1986).

11. Skern, T. et al. Nucleic Acids Res. 13, 2111-2126 (1985).

12. Dimmock, N. J., Trends biochem. Sci. 12, 70-75 (1987).

13. Luo, M. et al. Science 235, 182-191 (1987).

13. Luo, M. et al. Science 235, 182-191 (1987).
14. Chedid, L. et al. Biochem. biophys. Res. Commun. 117, 908-915 (1983).

14. Chedid, L. et al. Biochem, biophys. Res. Commu
15. Werner, G. et al. J. Virol 57, 1084-1093 (1986).

16. Towbin, H., Staehelin, T. \& Gordon, J. Proc. natn. Acad. Sci. U.S.A. 76, $4350-4354$ (1979)

17. Green, N. et al. Cell 28, 477-487 (1982).

\section{A c-erb-A binding site in rat growth hormone gene mediates trans-activation by thyroid hormone}

\author{
Christopher K. Glass*, Rodrigo Franco*†, \\ Cary Weinberger $\neq$, Vivian R. Albert*, \\ Ronald M. Evans $\ddagger \S \&$ Michael G. Rosenfeld*§
}

* Centre for Molecular Genetics and † Department of Biology, Eukaryotic Regulatory Biology Program, School of Medicine, University of California, San Diego, La Jolla, California 92093, USA

¥ Salk Institute, La Jolla, California 92037, USA

$\S$ Howard Hughes Medical Institute

The substance 3,5,3-triiodothyronine $\left(\mathrm{T}_{3}\right)$ stimulates growth hormone gene transcription in rat pituitary tumour cells ${ }^{1-4}$. This stimulation is thought to be mediated by the binding of nuclear $T_{3}$ receptors to regulatory elements $5^{\prime}$ to the transcriptional start site $^{5-8}$. Understanding of the mechanism by which thyroid hormone activates gene transcription has been limited by failure to purify nuclear $T_{3}$ receptors because of their low abundance, and by the absence of defined $T_{3}$ receptor-DNA binding sites affecting $T_{3}$ regulation. Recently, human and avian $c-e r b-A$ gene products have been shown to bind thyroid hormone with high affinity ${ }^{9,10}$ and to have a molecular weight and nuclear association characteristic of the thyroid hormone receptor. In the present report, we describe the development of an avidin-biotin complex DNA-binding assay which can detect specific, high-affinity binding of rat pituitary cell $T_{3}$ receptors to the sequence 5'CAGGGACGTGACCGCA3', located 164 base pairs $5^{\prime}$ to the transcriptional start site of the rat growth hormone gene. An oligonucleotide containing this sequence transferred $T_{3}$ regulation to the herpes simplex virus thymidine kinase promoter in transfected rat pituitary GC2 cells, and specifically bound an in vitro translation product of the human placental $c-e r b-A$ gene. The data provide supporting evidence that the human $c-e r b-A$ gene product mediates the transcriptional effects of $T_{3}$ and also that GC2 cell nuclear extracts contain additional factors that modify the binding of pituitary $T_{3}$ receptors to the rat growth hormone gene $T_{3}$ response element.

To identify the cis-active element in the growth hormone $(G H) 5^{\prime}$ flanking genomic sequence necessary for $\mathrm{T}_{3}$ regulation we used a series of $5^{\prime}$-deleted fragments of the rat $G H$ gene, fused to the bacterial chloramphenicol acetyltransferase (CAT) gene and transfected into rat pituitary GC2 cells (Fig. 1a). A $5^{\prime}$ deletion to -235 base pairs $(\mathrm{bp})$ from the transcriptional start (CAP) site transferred regulation to $\mathrm{T}_{3}$ (4.6-fold, Fig. 1a), equivalent to constructions containing 1.7 kilobases $(\mathrm{kb})$ or $307 \mathrm{bp}$ of 5 -flanking rat $G H$ information (data not shown), in agreement with previous studies ${ }^{5,6}$. (Nucleotide positions are numbered relative to the CAP site, negative position numbers being $5^{\prime}$ to it.) Deletions containing less than $235 \mathrm{bp}$ of $5^{\prime}$ flanking $G H$ information could not be assayed for $\mathrm{T}_{3}$ induction because the levels of $C A T$ expression in the absence of $\mathrm{T}_{3}$ were not significantly above background. To overcome this problem, a rat prolactin enhancer element ${ }^{11}$ was fused proximal to fragments of the rat $G H$ gene containing 181 and $107 \mathrm{bp}$ of $5^{\prime}$ flanking information. The 5 '-deleted fragment extending to position -181 gave 2.6 -fold induction by $\mathrm{T}_{3}$ and further deletion to position -107 from the CAP site abolished $\mathrm{T}_{3}$ regulation (Fig. 1a).

To assay $3^{\prime}$ deletions, fragments of the rat $G H$ gene were fused to the herpes simplex virus thymidine kinase (HSV $t k$ ) promoter. A fragment of the $G H$ gene extending from position -235 to position -45 from the CAP site produced 2.5 - and 2.3 -fold stimulations of CAT activity when fused to the $t k$ promoter in native and inverse orientation, respectively (Fig. 1b). A 90 -bp fragment extending from positions 235 to $145 \mathrm{bp}$ 